\title{
Issue 60
}

I. GEOGRAPHY OF RECREATION AND TOURISM: THEORETICAL AND APPLIED ISSUES

Myronets N.R., Romaniv O.Y., Yaromenko O.V. DOOMED TO DEATH: ABORTIONS AND ABORTION TOURISM

Budarina K.O., Sharan L.O., Bondar N.P., Gubenya V.A. EXPEDIENCY OF INTRODUCING A CRAFT CAVE IN A HOSPITALITY INSTITUTION

Matviienko N. M., Matviienko V.M. TOURIST-RECREATIONAL RESOURCES OF JAPAN

Udovitsa O.F., Shekera S.S. CAUSES AND PREVENTION OF MANAGEMENT CONFLICTS IN THE FIELD OF ACTIVITY OF HEADS OF DOMESTIC ENTERPRISES OF THE TOURIST BUSINESS

Sokolovsky V.A., Shchegolieva I. V. EVENT TOURISM OF THE MIDDLE DNIEPER REGION AS A STRATEGIC DIRECTION OF REGIONAL DEVELOPMENT

Nesterchuk I.K. GASTRONOMY BRAND OF THE TERRITORY (ON THE EXAMPLE OF THE CULTURAL AND HISTORICAL HERITAGE OF THE RIGHT-BANK POLISSIA)

Gladkey O.V., Kilivnuk V.S. THE EXPERIENCE OF NON-STATE MEDICAL-TECHNOLOGICAL AND LOCAL HISTORY MUSEUMS' COLLECTION CREATION ON THE TERRITORY OF SANATORIUM "AVANGARD" IN NEMYRIV CITY, VINNITSYA REGION 
II. CURRENT PROBLEMS OF SOCIAL GEOGRAPHY AND COUNTRY STUDIES

Batychenko S.P. FEATURES OF FAMILY POLICY IN EUROPE

Smochko N.M. LAND RESOURCE POTENTIAL OF THE TRANSCARPATHIAN REGION AS A FACTOR OF AGRICULTURAL MONOSYSTEM DEVELOPMENT

III. NATURAL GEOGRAPHY: THEORY AND PRACTICE

Smilii P.M., Melniychuk M.M. ECOLOGICAL ASSESSMENT OF SURFACE WATER QUALITY OF ROSTAVYTSIA RIVER

INFORMATION ABOUT AUTHORS

1. Batychenko Svitlana Pavlivna - Candidate of Geographic Sciences, junior researcher, Taras Shevchenko National University of Kyiv, research №19БФ-042-01M Kyiv, Ukraine, e-mail: batychenko_sveta@ukr.net.

2. Bondar Natalia Petrovna - Candidate of Technical Sciences, Associate Professor, Assistant Professor of Hotel and Restaurant Business Department, National University of Food 


\section{Issue 60}

Written by Administrator

Monday, 12 April 2021 14:28 - Last Updated Wednesday, 14 April 2021 16:56

Technologies, Kyiv, Ukraine.

3. Budarina Kateryna Oleksiivna - Master of Hotel and Restaurant Business Department, National University of Food Technologies, Kyiv, Ukraine.

4. Gladkey Oleksandr Vitaliyovych - Doctor of Geography Sciences, Professor Kyiv National University of Trade and Economics, Kyiv, Ukraine, e-mail: alexander.gladkey@gmail.com.

5. Gubenya Vyacheslav Alexandrovich - Candidate of Technical Sciences, Associate Professor, Assistant Professor of Hotel and Restaurant Business Department, National University of Food Technologies, Kyiv, Ukraine

6. Kilivnuk Volodymyr Stepanovytch - Candidate of Medical Sciences, Associate Professor, M. Pirogov Vinnitsya National Medical University, Vinnitsya, Ukraine, e-mail: vs.kulivnuk@ukr.net.

7. Matviienko Nataliia Mykolaivna - PhD Geography, Associate Professor, Assistant Professor of Country Studies and Tourism Department, Faculty of Geography, Taras Shevchenko National University of Kyiv, Kyiv, Ukraine, e-mail: rika11@ukr.net.

8. Matviienko Volodymyr Mykolaiovych - PhD Geography, Associate Professor, Assistant Professor of Economic and Social Geography Department, Faculty of Geography, Taras Shevchenko National University of Kyiv, Kyiv, Ukraine, e-mail: ozero11@ukr.net.

9. Myronets Nina Rostislavivna - Candidate of History, Associate Professor, Dean of the Faculty of European Education, International University of Economics and Humanities Academician Stepan Demianchuk, Rivne, Ukraine, e-mail: nina_myr@ukr.net.

10. Melniychuk Mykhailo Mykhailovych - Candidate of Geographical Sciences, Associate Professor, Assistant Professor of Department of Physical Geography, Eastern European Lesya Ukrainka National University, Lutsk, Ukraine, e-mail: melniichuk.mm@gmail.com 
11. Nesterchuk Inna Konstantinovna - Candidate of Geographical Sciences, Associate Professor, Head of the Department of Tourism, Zhytomyr National Argoecological University, Zhytomyr, Ukraine, e-mail: nester_geoek@ukr.net.

12. Romaniv Oksana Yakivna - Candidate of Geography, Associate Professor, Assistant Professor of Geology and Hydrology Department, National University of Water and Environmental Engineering, e-mail: okromaniv@gmail.com.

13. Smilii Pavlo Mykolaiovych - Graduate Student, Eastern European Lesya Ukrainka National University, Lutsk, Ukraine.

14. Smochko Nataliia Mykhailivna - Candidate of Geographical Sciences, Associate Professor, Head of Tourism and Geography Department, Mukachevo State University, Mukachevo, Ukraine, e-mail: natazak@ukr.net, http://orcid.org/0000-0002-2440-5737.

15. Sokolovsky Victor Anatolievich - a senior lecturer of the Department of tourism and air transport, Flight Academy of the National Aviation University, Kropyvnytskyi, Ukraine.

16. Udovitsa Oleg Fedorovych - Candidate of Pedagogical Sciences, Associate Professor, Odesa National Academy of Food Technologies, Odesa, Ukraine, e-mail: udovitsaoleg@gmail.com.

17. Sharan Larisa Alexandrovna - Candidate of Technical Sciences, Associate Professor, Assistant Professor of Hotel and Restaurant Business Department, National University of Food Technologies, Kyiv, Ukraine, e-mail: Larisharan@ukr.net.

18. Shchegolieva Inna Valentinovna - Associate Professor, PhD (Pedagogics), Assistant Professor of Tourism And Air Transport Department, Flight Academy of the National Aviation University, Kropivnitsky, e-mail: inna.akvilon@gmail.com. 
19. Shekera Svetlana Sergiyivna - Candidate of Economic Sciences, Senior Lecturer, Odesa National Academy of Food Technologies, Odesa, Ukraine, e-mail: shekera.sveta@gmail.com.

20. Yaromenko Oksana Volodymyrivna - Candidate of Geography, Associate Professor, Head of the Department of Geography and Tourism, International University of Economics and Humanities Academician Stepan Demianchuk, Rivne, Ukraine, e-mail: Yaromenko_ov@ukr.net. 